\title{
Review
}

\section{Activity of Manganese Dioxide (On Its Battery Reaction)}

\author{
Akio ERA \\ Mitsui Mining \& Smelting Co., Ltd., Nihonbashi-Muromachi, Chuo-ku, Tokyo \\ Present address: Nippon Yttrium Co., Ltd., 500, Minamiura, Shimorenjyaku, Mitaka, Tokyo.
}

Received Nov. 10, 1967

\section{Introduction}

Manganese dioxide used as the active material of positive electrode in a dry battery is found in the nature and also produced by chemical synthesis as well as by electrolysis. The discharge performance of dry batteries depends on the kind of manganese dioxide to be used. And the term "activity" (or "depolarizing capacity") has frequently been used to express the property of this substance as an active material. However, this term has an indistinct conception and lacks a definite criterion for evaluation. Generally there is adopted a method whereby test-batteries are prepared and are measured their discharge capacities. The term "discharge capacity", in this case, also posseses no definite conception. The magnitude of "discharge capacity" is affected widely by the technique of battery manufacture and the mode of discharge involved and, therefore, can not necessarily represent the intrinsic property of the manganese dioxide as the active material sufficiently. The conception of "available oxygen" has heretofore been adopted as the most straightfoward properties for the evaluation of manganese dioxide in its depolarizing capacity. However, the "available oxygen" content to be determined by either the oxalic acid method (otherwise referred to as sodium oxalate method 1) or the ferrous sulphate method ${ }^{2}$ ) is widely recognized to have no proportional relationship with the discharge capacity of battery. ${ }^{3)}$ Many studies showed that the crystalline structure is a more important factor in determining the discharge capacity of manganese dioxide. ${ }^{3), 4)}$

In the determination of the "available oxygen" by the oxalic acid method, the following chemical reaction is adopted;

$$
\begin{aligned}
& \mathrm{MnO}_{2}+\mathrm{C}_{2} \mathrm{O}_{4}^{2-}+4 \mathrm{H}^{+} \\
& =\mathrm{Mn}^{2+}+2 \mathrm{H}_{2} \mathrm{O}+2 \mathrm{CO}_{2}
\end{aligned}
$$

whereas in the case of the ferrous sulphate method the following chemical reaction is involved;

$$
\begin{aligned}
& \mathrm{MnO}_{2}+2 \mathrm{Fe}^{2+}+4 \mathrm{H}^{+} \\
& \quad=\mathrm{Mn}^{2+}+2 \mathrm{Fe}^{3+}+2 \mathrm{H}_{2} \mathrm{O} .
\end{aligned}
$$

In these chemical reactions, manganese dioxide is reduced to $\mathrm{Mn}(\mathrm{II})$, and the all of reduced manganese(II) is dissolved into the solution present. The reactions in eqn. (1) and (2) are considerably different from that actually taking place in the battery, which will be discussed later on.

Drotschmann ${ }^{5)}$ and Fukuda ${ }^{6)}$ experimented independently on the reaction of manganese dioxide with hydrazine in alkaline solutions of ammonium and of sodium hydroxide respectively, and then found that the reduction proceeds only to the stage of $\mathrm{Mn}$ (III), and the reaction product, $\mathrm{MnOOH}$, does not dissolve into the solution but remains on the surface of manganese dioxide particles. They described that the re- 
action resembled the electrochemical reduction which occurs in the dry battery, and proposed that their method should be used as a measure in determining the "activity" of manganese dioxide. Certainly, this might be an excellent method and is now used so widely that some one considers the term "activity" representing the evaluated value by the hydrazine method.7) Hirai, Manabe and Fukuda ${ }^{8}$ ) reported in their paper that there exists a correlation between the evaluated value by the hydrazine method and the discharge performance of test dry batteries. Although this method is an excellent one, it is still a chemical approximation for the electrochemical reaction taking place in the battery. The electrochemical properties, which the active material of battery is required to possess, of particular importance are the following three*:

i) High electrode potential

ii) Small change in potential at discharge

iii) Large quantity of electric current available per unit volume (discharge capacity)

These electrochemical properties may be referred to as the term "activity". Brenet ${ }^{9}$ ) stated, "A high activity corresponds practically to the possibility of releasing a maximum quantity of electricity with a maximum potential difference at the cell terminals over as long as a period as possible".

From the practical point of view, however, what method should be used to determine the "activity" having such definition is quite a difficult problem. When a battery test is applied, there are many problems to be overcome. In order to understand the "activity" correctly, it is necessary to clarify what kinds of chemical and electrochemical reactions of manganese dioxide take place in the battery. Many studies were made on crystalline structure, thermal analyses, ion-exchange property, surface area determination by the BET method, magnetic susceptibility and other physical and chemical properties of manganese dioxide, but there still remain points yet to be elucidated as to the relationship between such properties and the "activity".
In this paper, the author outlines various studies published to date on manganese dioxide with respect to (1) chemical changes occurring in a battery during discharge, (2) discharge products of manganese dioxide electrode, and (3) discharge mechanism, and then discusses the physical and chemical properties of manganese dioxide affecting the activity.

\section{Chemical Changes of Electrolyte in Dry Battery During Discharge}

Cahoon and Heise ${ }^{10}$ ) investigated the change of $\mathrm{pH}$ of dry battery in the course of discharge through a constant resistance. The $\mathrm{pH}$ values have been observed to rise within the cathode mixture but fall in the neighbourhood of anode as the discharge proceeds, and the degree of $\mathrm{pH}$ increase is higher with the decreasing distance from the centre. Furthermore, it was observed that the $\mathrm{pH}$ change is not continuous but rather stepwise. Fukuda and Hirai $\left.{ }^{11}\right)^{\sim 15}$ ) made experiments on the influence of $\mathrm{ZnCl}_{2}$ concentration in electrolyte upon the discharge performance, and discussed on dynamic changes in a battery corresponding to the shape of discharge curve. They disclosed that the cause of temporary decrease in the terminal voltage during the continuous discharge is due to the temporary increase of the resistance of the electrolyte in the outermost layer of the bobbin, and the temporary decrease in the terminal voltage becomes more intensive and lasts for a longer period of time with the increase in concentration of zinc chloride. (See Fig. 1 and Fig. 2). They confirmed that the temporary increase in electrical resistance and its recovery corresponded to the formation of insoluble $\mathrm{ZnCl}_{2}-2 \mathrm{NH}_{3}$, and its transition to soluble $\mathrm{ZnCl}_{2}-4 \mathrm{NH}_{3}$, respectively. In the case of intermittent discharge, however, they did not observe any phenomenon of temporary fall but confirmed that the decrease in the terminal voltage due to increase in resistance of electrolyte of outermost part of bobbin and to increase in resistance of carbon particle network in the 


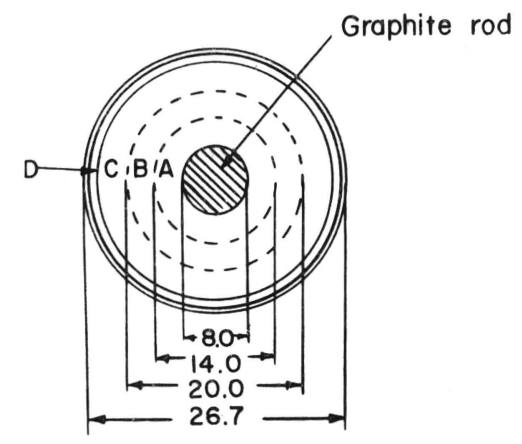

Fig. 1 Cell cross section, showing location of samples for $\mathrm{pH}$ measurements in Fig. 4 (M. Fukuda and T. Hirai)

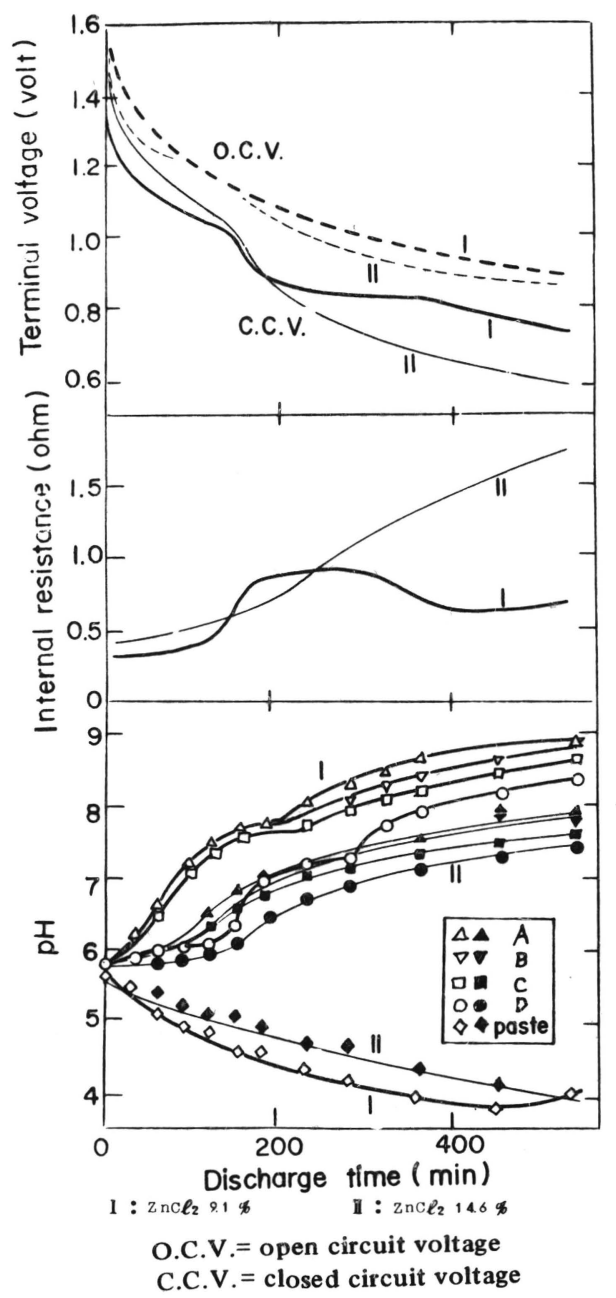

Fig. 2 Change of terminal voltage, internal resistance and $\mathrm{pH}$ value during $4 \mathrm{ohm}$ continuous discharge

(M. Fukuda and T. Hirai)
Table 1 Electroly te Composition of 6 test-cells Shown in Fig. 3

\begin{tabular}{c|c|c|c|c}
\hline \multirow{2}{*}{$\begin{array}{c}\text { Sample } \\
\text { No. }\end{array}$} & \multicolumn{3}{|c|}{ Composition (\%) } & \multirow{2}{*}{$\mathrm{pH}\left(20^{\circ} \mathrm{C}\right)$} \\
\cline { 2 - 4 } & $\mathrm{NH}_{4} \mathrm{Cl}$ & $\mathrm{ZnCl}_{2}$ & $\mathrm{H}_{2} \mathrm{O}$ & \\
\hline 1 & 27.0 & 9 & 73.0 & 4.47 \\
2 & 27.0 & 5 & 68.0 & 4.80 \\
3 & 27.0 & 10 & 63.0 & 4.74 \\
4 & 27.0 & 15 & 57.3 & 4.66 \\
5 & 28.2 & 20 & 51.8 & 4.56 \\
6 & 29.0 & 25 & 46.0 & 4.44 \\
\hline
\end{tabular}

innermost layer of the bobbin, revealing that the latter factor becomes predominant when the concentration of zinc chloride is low.

Fukuda and Hirai ascribed these influences of zinc chloride concentration in the electrolyte to the change of internal resistance of the battery, but they did not pay much consideration to the polarization of manganese dioxide electrode. As
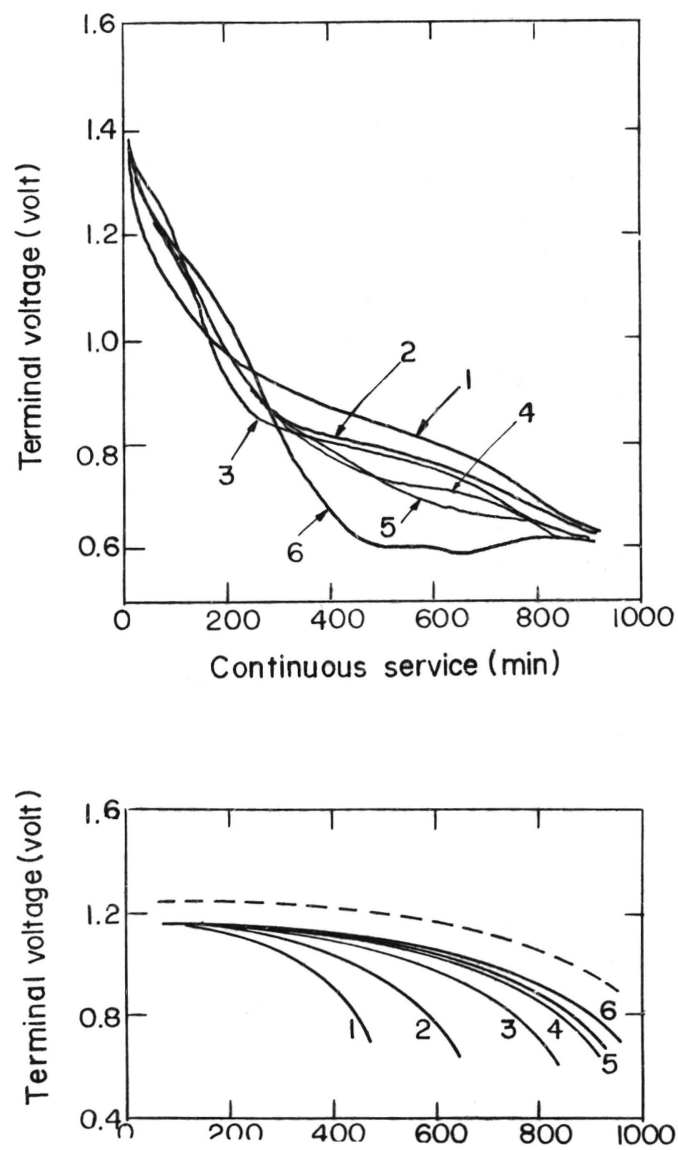

Fig. 3 Discharge curves of dry cells (M. Fukuda and T. Hirai) 
a dry battery contains an extremely limited quantity of electrolyte, the iR drop caused by the change in composition of electrolyte certainly seems to affect the voltage drop more than the polarization.

Drotschmann ${ }^{10}$, holds a view that the drop of terminal voltage due to the discharge can be explained solely by the change of $\mathrm{pH}$ value of the catholyte and anolyte of the battery. The change of $\mathrm{pH}$ value of the catholyte and of the anolyte due to the discharge was observed by Cahoon ${ }^{10), 17)}$ and Fukuda et $\mathrm{al}^{11}{ }^{1}$. The principal cause of the drop of terminal voltage during the discharge must be attributed to the change of $\mathrm{pH}$ value. At the same time, the increase of electrical resistance resulted from the change of composition of the electrolyte cannot be overlooked. However, the decrease in terminal voltage during the discharge cannot be explained sufficiently by the change of $\mathrm{pH}$ value and the change of electric resistance alone. It is necessary to take into account the polarization of the manganese dioxide electrode. Iwasaki, Morita, Nishi and Okada ${ }^{18)}$, Sasaki and Kozawa ${ }^{19)}$ studied independently the influence of concentration of zinc chloride on the discharge capacity of manganese dioxide electrode on a wet battery ${ }^{20}$ ) using a large quantity of electrolyte to minimize the change of composition and $\mathrm{pH}$ value of the electrolyte during the discharge and observed that the discharge capacity of manganese dioxide electrode increases with the increase in concentration of zinc chloride. Similar observation was also reported by Ferrell and Vosburgh ${ }^{21)}$. Era, Takehara and Yoshizawa ${ }^{22}$ made an attempt to explain the role of zinc chloride in the reaction of manganese dioxide electrode.

\section{Discharge Product}

An early theory of the discharge of manganese dioxide electrode was that hydrogen was the primary product, this being subsequently oxidized by manganese dioxide. The term "depolarization" has been derived from this theory. Although this term is still being used, such theory is no longer adopted. In 1882, Divers ${ }^{23}$ ) explained the polarization of manganese dioxide electrode based on the accumulation of discharge products such as $\mathrm{MnOOH}$ and $\mathrm{ZnMn}_{2} \mathrm{O}_{4}$ on the surface of manganese dioxide. Divers' explanation was not received until recently. Keller ${ }^{24}$ ) reported that the discharge results in the formation of a lower oxide of manganese and that this lower oxide forms a solid solution with $\mathrm{MnO}_{2}$, which decreases the electromotive force.

As the product of discharge of manganese dioxide electrode, there have been recognized $\mathrm{Mn}(\mathrm{II})$ ion $^{25)}$ 27) which dissolves into the electrolyte and a lower : oxide, $\mathrm{Mn}_{2} \mathrm{O}_{3}$, or oxyhydroxide, $\mathrm{MnOOH}$, in the solid phase $^{25), 28), 29 \text { ). Bode, Schmier and Brendt }}{ }^{30 \text { ) }}$ mentioned that the lower oxide produced by the discharge of gamma- $\mathrm{MnO}_{2}$ is different from that of beta- $\mathrm{MnO}_{2}$. i.e., in the case of gamma- $\mathrm{MnO}_{2}$, the product is alpha- $\mathrm{MnOOH}$ which has the same crystal structure as gamma- $\mathrm{MnO}_{2}$, while in the case of beta- $\mathrm{MnO}_{2}$, it is gamma-MnOOH which has a different phase from beta- $\mathrm{MnO}_{2}$. They observed that there is a proportional relationship between the equilibrium potential and the degree
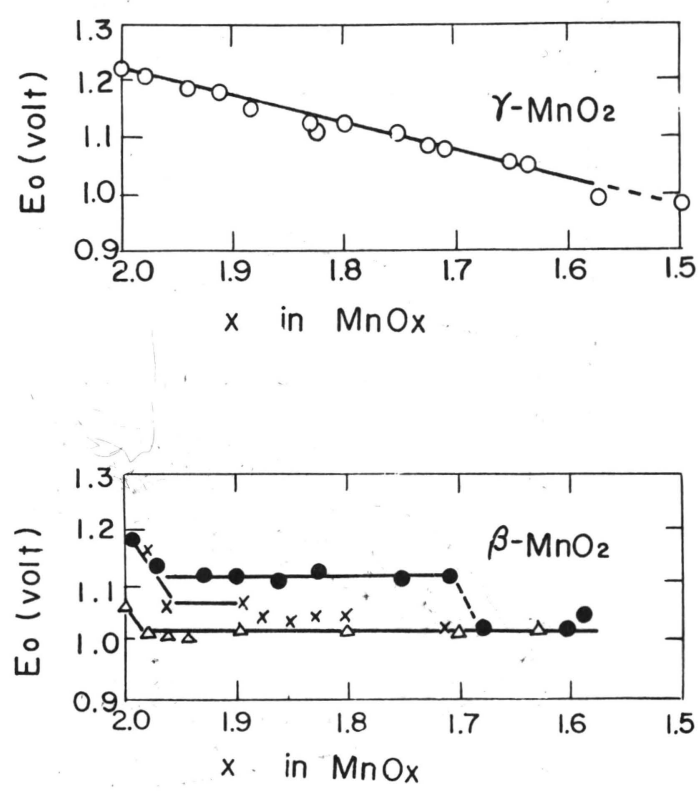

$\triangle$ unhydrous

- containing $4 \% \mathrm{H}_{2} \mathrm{O}$

$x$ containing $1 \% \mathrm{H}_{2} \mathrm{O}$

Fig. 4 Equilibrium electrode potential of $\gamma$ and $\beta-\mathrm{MnO}_{2}$ and their reduction product $(\mathrm{H}$. Bode, A. Schmier, and D. Brendt) 
of oxidation of gamma-MnO $\mathrm{M}_{2}$, as shown in Fig. 4 , while in the case of beta- $\mathrm{MnO}_{2}$ electrode, the equilibrium potential is a fixed value regardless of the oxidation degree. According to Vetter's theory ${ }^{31)}$ the electrode potential of a nonstoichiometric metal oxide (or hydroxide) electrode changes continuously depending on the oxidation degree when the electrode consists of a homogeneous phase, but the potential should remain unchanged when the electrode consists of two phases which exist in equilibrium. Bode, Schmier and Brendt found empirically the following equation among the two magnitudes, oxidation degree of gamma- $\mathrm{MnO}_{2}, \mathrm{x}$ in $\mathrm{MnO}_{\mathrm{x}}$, and electrode potential $E$;

$$
E=\mathrm{a}+\mathrm{bx}
$$

where $\mathrm{a}$ and $\mathrm{b}$ are constants. Johnson and Vosburgh $^{32)}$, on the other hand, obtained experimentally the following equation;

$$
E=E O+k \log \left(\mathrm{mol} \% \mathrm{MnO}_{2} / \mathrm{mol} \% \mathrm{MnOOH}\right),
$$

where EO and $k$ are constants with $\mathrm{k}$ being 73 $\mathrm{mV}$. As is pointed out by Era, Takehara, Yoshizawa $^{33)}$ or Kozawa ${ }^{34)}$, the equation (4) is identical to the Nernst equation:

$$
E=E O+\mathrm{RT} / \mathrm{F} \cdot \ln \left(a_{\mathrm{MnO}_{2}} / a_{\mathrm{MnOOH}}\right)
$$

which is derived from the following electrochemical reaction,

$$
\mathrm{MnO}_{2}+\mathrm{H}^{+}+e^{-} \leftrightarrows \mathrm{MnOOH}
$$

Accordingly, the relationship between the value " $\mathrm{X}$ " and the electrode potential is represented

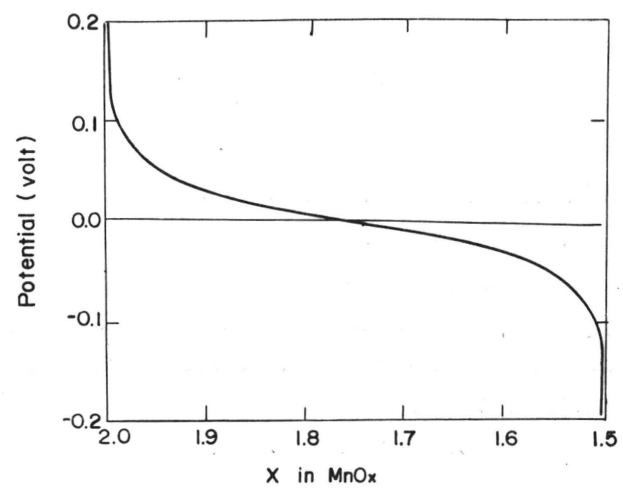

Fig. 5 Equilibrium potential curve (A. Kozawa) graphically as shown in Fig. 5. This equation (4) does not show good agreement with experimental values in the case of $\mathrm{a}_{\mathrm{MnO}_{2}} \gg \mathrm{a}_{\mathrm{MnOOH}}$

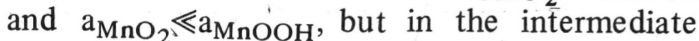
region between the two extreme cases, it shows quite satisfactory agreement with experimental values. At any rate, a manganese dioxide electrode gradually changes to a lower oxide as the discharge reaction proceeds, and this might be the main cause of decrease in the terminal voltage of dry battery.

Matsuno ${ }^{35)}$ studied the exhausted bobbin of dry battery by X-ray diffraction and concluded the final product of discharge to be $\mathrm{Mn}_{3} \mathrm{O}_{4}$. McMurdie $^{36)}$, and Copeland and Griffith ${ }^{28}$ ) reported the product to be $\mathrm{ZnO} \cdot \mathrm{Mn}_{2} \mathrm{O}_{3}$ which has the same structure as naturally occurring hetaerolite and gives an $\mathrm{X}$-ray diffraction pattern resembling that of $\mathrm{Mn}_{3} \mathrm{O}_{4}$. They also found $\mathrm{MnOOH}$ being another discharge product, which must be, however, further reduced to lower oxides with the progress of discharge, while $\mathrm{ZnO} \cdot \mathrm{Mn}_{2} \mathrm{O}_{3}$ is no longer reduced. And they concluded that the formation of $\mathrm{ZnO} \cdot \mathrm{Mn}_{2} \mathrm{O}_{3}$ is rather unprofitable to discharge capacity. However, it is well known that the presence of a large quantity of zinc chloride in the electrolyte of dry battery serves to increase the discharge capacity, particularly in case of light drain. Many workers proved experimentally that the electrolyte containing zinc chloride gives a larger discharge capacity than the electrolyte including no zinc chloride ${ }^{18), 19), 21 \text { ) }}$

McMurdie, Craig and Vinal ${ }^{37)}$ discovered that $\mathrm{ZnO} \cdot \mathrm{Zn}_{2} \mathrm{O}_{3}$ is formed by merely allowing manganese dioxide to stand with the neutral solution containing $\mathrm{Mn}^{2}+$ ion and $\mathrm{Zn}^{2+}$ ion:

$$
\underset{\mathrm{ZnO} \cdot \mathrm{Mn}_{2} \mathrm{O}_{3}+4 \mathrm{H}^{+}}{\mathrm{MnO}_{2}}+\mathrm{Mn}^{2+}+2 \mathrm{Zn}_{2}^{2+} \mathrm{O}=
$$

In addition, they found that $\mathrm{MnOOH}$ is formed from $\mathrm{MnO}_{2}$ and $\mathrm{Mn}^{2+}$ ion in the absence of $\mathrm{Zn}^{2+}$ ion,

$$
\mathrm{MnO}_{2}+\mathrm{Mn}^{2+}+2 \mathrm{H}_{2} \mathrm{O}=2 \mathrm{MnOOH}+2 \mathrm{H}^{+}
$$

Griffith $^{38)}$ mentioned that hetaerolite is not a primary product of discharge reaction, but it is rather a secondary product. This view is supported by Cahoon, Heise et al. ${ }^{10)}$ 


\section{Discharge Mechanism}

As mentioned above, $\mathrm{Mn}$ (II) ion, $\mathrm{MnOOH}$, $\mathrm{Mn}_{3} \mathrm{O}_{4}, \mathrm{ZnO} \cdot \mathrm{Zn}_{2} \mathrm{O}_{3}$ and the like have been found to be the discharge product. In this chapter, discussions will be made on what the primary product of discharge reaction is, and what the succeeding chemical changes take place.

There are two different proposals for the primary product of discharge reaction; one taking Mn(II) and the other, Mn(III). Because of the low solubility of $\mathrm{Mn}^{3+}$ ion, Brenet ${ }^{29}$ ) considered that the primary product of discharge reaction is not $\mathrm{MnOOH}$ but rather $\mathrm{Mn}$ (II) and that $\mathrm{MnOOH}$ is a mixture of equal parts of $\mathrm{Mn}(\mathrm{II})$ and $\mathrm{Mn}(\mathrm{III})$. Cahoon 10),25),39) agrees with this view.

$$
\mathrm{MnO}_{2}+4 \mathrm{H}^{+}+2 \mathrm{e}^{-}=\mathrm{Mn}^{2+}+2 \mathrm{H}_{2} \mathrm{O}
$$

Manganous ion thus formed may react with the unreacted $\mathrm{MnO}_{2}$ to give $\mathrm{MnOOH}$ according to the reaction equation(8). If the electrolyte contains $\mathrm{Zn}^{2+}$ ion, there is additionally involved the reaction such as shown by equation(7). Cahoon explained the potential recovery after opening the circuit by ascribing it to the reaction of equation(8), and he further mentioned that this reaction is liable to occur more readily in active manganese dioxide capable of quicker potential recovery. The electrode potential, however, ought to decrease as this reaction takes place. In fact, Wadsley and Walkley ${ }^{40}$ ) observed that the electrode potential of manganese dioxide falls when it is kept in a solution containing $\mathrm{Mn}^{2+}$ ion. This means that the view of Cahoon et al. seems to have room for futher discussion. ${ }^{*}$

Neuman and Fink ${ }^{27)}$ proposed the theory of direct reduction to $\mathrm{Mn}(\mathrm{II})$. They interpreted that in a discharge curve shown in Fig. 6, the earlier part of discharge, in which an abrubt voltage drop is observed, corresponds to the reaction converting $\mathrm{Mn}(\mathrm{IV})$ into $\mathrm{Mn}(\mathrm{III})$, while the part of comparatively smooth voltage drop in the intermediary period corresponds to the reaction coverting $\mathrm{Mn}(\mathrm{IV})$ into $\mathrm{Mn}(\mathrm{II})$.

They have drawn this conclusion from their observation that the rate of $\mathrm{H}^{+}$ion consumption,

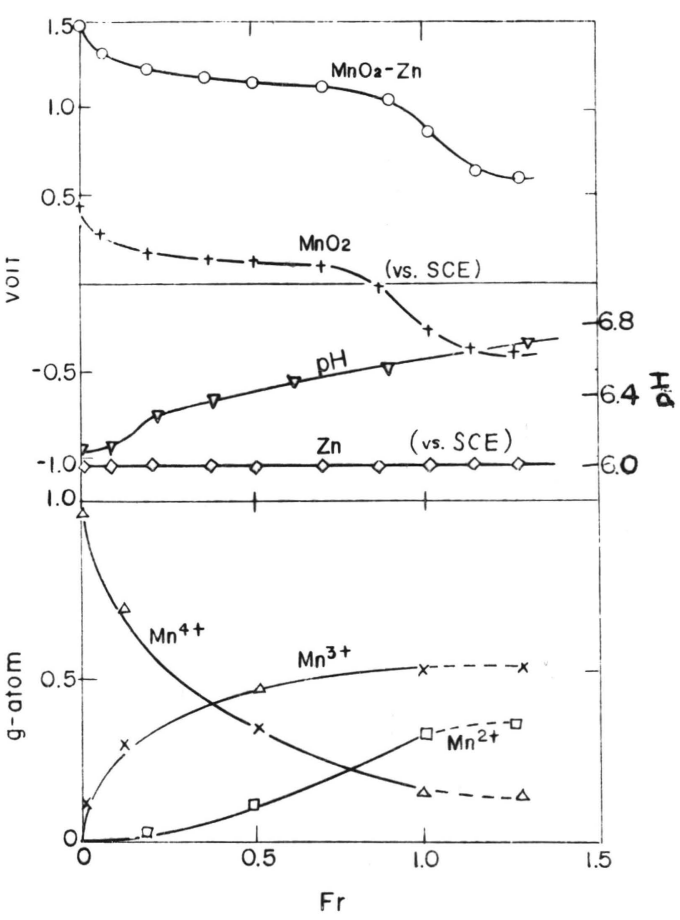

Fig. 6 Discharge of $\mathrm{MnO}_{2}$ cell ( $\mathrm{K}$. Nuemann and W. Fink)

which occurs as a consequence of discharge reaction, differs between the reaction of $\mathrm{Mn}(\mathrm{IV})$, $\mathrm{Mn}(\mathrm{III})$ and that of $\mathrm{Mn}(\mathrm{IV}) \rightarrow \mathrm{Mn}(\mathrm{II})$, as shown below.

In the case of reduction from $\mathrm{MnO}_{2}$ to $\mathrm{Mn}_{2} \mathrm{O}_{3}$;

$$
\begin{array}{r}
\mathrm{MnO}_{2}+\mathrm{H}^{+} \rightarrow 1 / 2 \mathrm{Mn}_{2} \mathrm{O}_{3}+1 / 2 \mathrm{H}_{2} \mathrm{O}+1 \mathrm{Fr} \\
\mathrm{H}^{+} / \mathrm{Fr}=1,
\end{array}
$$

while in the case of reduction from $\mathrm{MnO}_{2}$ to $\mathrm{Mn}^{2+}$;

$$
\begin{array}{r}
\mathrm{MnO}_{2}+4 \mathrm{H}^{+} \rightarrow \mathrm{Mn}^{2+}+2 \mathrm{H}_{2} \mathrm{O}+2 \mathrm{Fr} \\
\mathrm{H}^{+} / \mathrm{Fr}=2 .
\end{array}
$$

The change of $\mathrm{pH}$ value is not very large in equation (10), whereas is quite large in equation (11). The experimental results suggest that the change of $\mathrm{pH}$ value is comparatively small in the earlier part of discharge but is increased with the progress of discharge.

It is well known that the electrode potential

* The progress of the reaction of equation(8) will cause lowering the $\mathrm{pH}$ value, which make the potential nobler. 


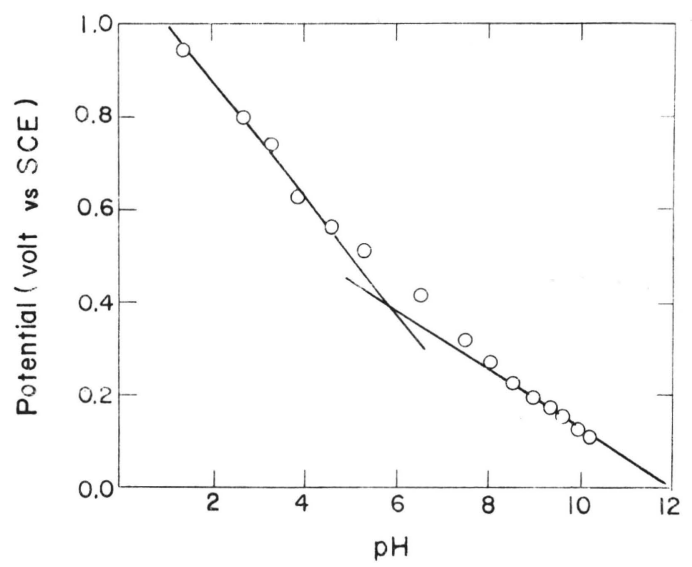

Fig. $7 \mathrm{pH}$ and potential of $\mathrm{MnO}_{2}$ (H.F. McMurdie, D. N. Craig, and G. W. Vinal)

of manganese dioxide changes depending on the $\mathrm{pH}$ value of the surrounding solution. Craig and Vinal ${ }^{37)}$ confirmed that the value of $\mathrm{E} / \mathrm{pH}$ is 0.06 volt in the alkaline solution but 0.12 volt in the acidic solution as shown in Fig. 7, and accordingly concluded that the electrode reaction progresses on the lower $\mathrm{pH}$ range in the following manner;

$$
\mathrm{MnO}_{2}+4 \mathrm{H}^{+}+2 e^{-} \rightarrow \mathrm{Mn}^{2+}+\mathrm{H}_{2} \mathrm{O},\left(9^{\prime}\right)
$$

whereas on the higher $\mathrm{pH}$ range as follows:

$$
2 \mathrm{MnO}_{2}+2 \mathrm{H}^{+}+2 e^{-} \rightarrow \mathrm{Mn}_{2} \mathrm{O}_{3} \cdot \mathrm{H}_{2} \mathrm{O} \text {. }
$$

Cahoon ${ }^{41)}$, Muraki and Shinoda ${ }^{42)}$, and Kozawa and Sasaki ${ }^{43} 45$ ), however, observed no such bend in the linear curve representing the relationship between potential and $\mathrm{pH}$ value but confirmed the relationship of $\mathrm{E} / \mathrm{pH}=0.06$ volt throughout the entire $\mathrm{pH}$ range (0 to 14$)$,. The charge transfer reaction may, therefore, be concluded to have more possibility of following the reaction of equation(5) than that of equation(9).

The changes taking place during the discharge was explained by Coleman ${ }^{46)}$ as follows, $\mathrm{MnO}_{2}$ receives $\mathrm{H}^{+}$from the electrolyte and $e^{-}$ from the electrode to give $\mathrm{MnOOH}$. And this view is supported by Ferrell and Vosburgh ${ }^{19}$ ), Scott ${ }^{47)}$, Kozawa ${ }^{34), 49)}$ and Era, Takehara and Yoshizawa ${ }^{33), 50)}$. Ferrell and Vosburgh ${ }^{21)}$ made a series of discharge experiments using the manganese dioxide electrode, which was prepared by the electrodeposition on a graphite rod from an acidified manganous sulphate solution at high temperature, and observed that in the case of discharge in neutral electrolytes, the closed circuit potential continued to fall with the discharge time and on breaking the circuit the potential began to rise but could not reach to initial value. The potential drop due to discharge consists of open-circuit potential decrease and polarization, and furthermore that the growth of polarization and the rate of recovery are extremely slow as can never be seen in other electrodes. They concluded that this polarization differs from the mere activiation polarization or from the concentration polarization of the electrolyte solution.

Coleman ${ }^{46)}$ considered that a diffusion process within the solid phase of manganese dioxide plays an important role in the phenomena of polarization of dry battery. The point of this theory is that as a result of discharge, $\mathrm{MnOOH}$ is formed on the surface of $\mathrm{MnO}_{2}$ electrode and it diffuses into the interior of the electrode. In actual practice the diffusion of $\mathrm{MnOOH}$ can be effected by the movement of electrons and protons only.

The solid phase diffusion theory was supported by $\mathrm{Scott}^{47)}$, Kornfeil ${ }^{48)}$, and Era, Takehara and Yoshizawa ${ }^{50}$ ). They made an attempt to explain the potential-time relationship by the mathematical solution of Fick's diffusion equation. The explanation of potentialtime curve by the solid phase diffusion theory requires the assumption that:

(a) The potential of manganese dioxide electrode is determined by the composition at the surface ${ }^{51)}$, and

(b) The potential can be represented by the following equation ${ }^{32}$ );

$$
E=E_{0}+R T / F \cdot \ln \left(a_{\mathrm{MnO}_{2}} / a_{\mathrm{MnOOH}}\right)
$$

It appears possible to consider the process of charge transfer to be as in a quasi-equilibrium state, provided that the rate determining step in the overall discharge reaction is the diffusion process which follows the charge transfer reaction, so that the Nernst equation is valid even when polarization proceeds 33 ).

As $\mathrm{Mn}^{2+}$ ion concerns, which is another product of discharge reaction, Chreitzberg, Allenson and Vosburgen ${ }^{26)}$ proposed a different 
view from that of Cahoon ${ }^{10), 25), 39) . ~ C a h o o n ~}$ mentioned that $\mathrm{Mn}^{2+}$ ion is the primary product of discharge reaction, whereas Vosburgh et al. said that this ion is not observed in the earlier part of discharge in the electrolytes having relatively high $\mathrm{pH}$ values but it appeared in the later part of discharge. These observations lead to the assumption that $\mathrm{MnOOH}$ is formed as the primary product, then it gives rise to the following disproportionation reaction;

$$
2 \mathrm{MnOOH}+2 \mathrm{H}^{+}=\mathrm{Mn}^{2+}+\mathrm{MnO}_{2}+2 \mathrm{H}_{2} \mathrm{O}
$$

Yoshizawa and Vosburgh ${ }^{52}$ ) studied the electrode phenomena of manganese dioxide in the acid electrolyte, and concluded that the relation of overpotential to current density and the shapes of the growth and decay curves can be explained quantitatively on the assumption that the primary reduction product is $\mathrm{MnOOH}$ which will undergo the reaction of equation(12) and this reaction being the rate determining step in the overall discharge process.

It was clarified ${ }^{53}$ ) that the $\mathrm{MnOOH}$ removal is carried out by both of the above disproportionation reaction and the solid phase diffusion, and the former process predominates in the acid solution, while the latter in the alkaline solution. As regards the neutral solution, Scott ${ }^{47}$ ) and Kornfeil ${ }^{48)}$ discussed that the remova! of $\mathrm{MnOOH}$ is effected only by the solid phase diffusion. In the neutral solution, however, the dissolution of $\mathrm{Mn}^{2+}$ ion is observed with the progress of discharge. This phenomenon cannot be explained without assuming that the disproportionation reaction occurs together with the solid phase diffusion. The ratio of the disproportionation reaction to the solid phase diffusion is affected not only by the compositon of electrolyte $\left(\mathrm{pH}, \mathrm{NH}_{4} \mathrm{Cl}\right.$ and/or $\mathrm{ZnCl}_{2}$ concentration), but also by the intensity and the mode of discharge.

Era, Takehara and Yoshizawa ${ }^{54)}$ made a comparison test of various electrolytic manganese dioxides which were different from each other in activity, and observed that the man-

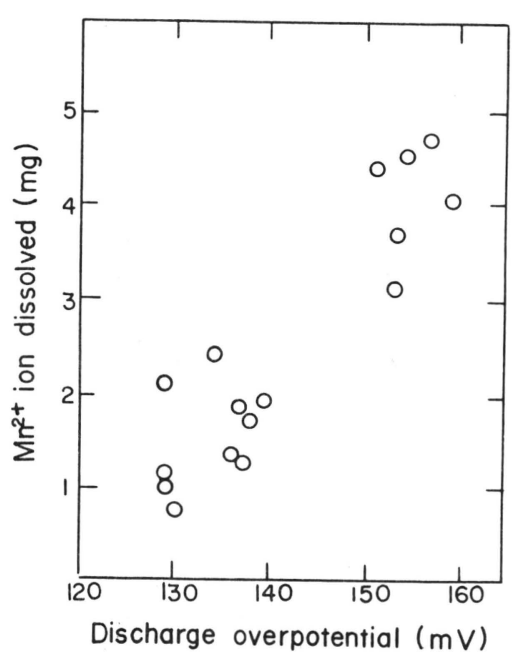

Electrolyte solution, $25 \% \mathrm{NH}_{4} \mathrm{Cl}, 10 \% \mathrm{ZnCl}, \mathrm{pH} 5.0$

Fig. 8 Relation between the discharge overpotential and the quantity of $\mathrm{Mn}^{2+}$ ion dissolved during discharge (A. Era, Z. Takehara, and $S$. Yoshizawa)

ganese dioxide exhibiting a high discharge overpotential produced much amount of $\mathrm{Mn}^{2+}$ ion during discharge than the manganese dioxide of lower overpotential as shown in Fig 8. A similar phenomenon was also observed by Appelt and

Pural $^{55)}$ with the use of natural manganese dioxide comparing with electrolytic one. They observed that the quantity of $\mathrm{Mn}^{2+}$ ion dissolved after discharge is much greater in natural manganese dioxide which shows greater polarization and smaller discharge capacity than in electrolytic manganese dioxide. According to the theory mentioned earlier, the fact the quantity of $\mathrm{Mn}^{2+}$ ion dissolved being greater means that the disproportionation reaction does occur much in the system. This phenomenon can be explained as follows; The electrochemical activity of manganese dicxide depends mainly upon the diffusibility of $\mathrm{H}^{+}$in the solid phase. When a manganese dioxide which is relatively inactive and thus shows higher overpotential is dis- 
charged, between the two $\mathrm{MnOOH}$ removal processes, the disproportionation reaction has to increase because the $\mathrm{H}^{+}$diffusion is more resistive.

If the activity of manganese dioxide might be defined as the rate of discharge reaction, or more precisely of the rate determining step in the overall discharge process, then the activity corresponds to the diffusion coefficient of solid phase diffusion rather than the rate constant of disproportionation reaction. Brouillet, Grund, Jolas and Mellet ${ }^{56)}$ advanced a view that the activity of manganese dioxide can be represented by $S \sqrt{ } D$ (where $\mathrm{S}$ denotes the ratio of effective surface area to total area, and $\mathrm{D}$ is the diffusion coefficient of $\mathrm{H}^{+}$within the solid phase).

\section{Physical and Chemical Properties} Affecting Activity

If $S \sqrt{D}$ can be one criterion for determining the activity of manganese dioxide, it will become necessary to discuss factors affecting $S$ and $D$, namely solid interior factors and surface factors.

It is known that the water contained in electrolytic manganese dioxide consists of moisture which can be removed reversibly at 100 to 110 ${ }^{\circ} \mathrm{C}$ and combined water which can be removed irreversibly at temperatures above $120^{\circ} \mathrm{C}^{57), 58)}$. It is also a well-known fact that the activity is greater with the increasing amount of this combined water in the manganese dioxide ${ }^{59)}, 19$ ). Brenet ${ }^{57)}$ said that this combined water serves to promote the movement of $\mathrm{H}^{+}$in the solid phase. Era, Takehara and Yoshizawa ${ }^{22}$ ) arrived at the knowledge that the increase in polarization of manganese dioxide due to heating is not found in the case of acid solution but is found in case of neutral and alkaline solutions, and that the increase in polarization becomes maximum in the alkaline solution, comfiming the existence of a close relationship between the combined water and thee solid phase diffusion of $\mathrm{H}^{+}$. Glemser and Meisiek 60$), 61$ ) reported that the combined water exists as $\mathrm{OH}$ group. Brenet ${ }^{62}$ ) proposed that the activity of manganese dioxide is governed by the $\mathrm{OH}$ group and that gamma- $\mathrm{MnO}_{2}$ being more active than beta- $\mathrm{MnO}_{2}$ is not due to the crystal structure of gamma-type but to the presence of $\mathrm{OH}$ group.

The surface characteristics is another factor of

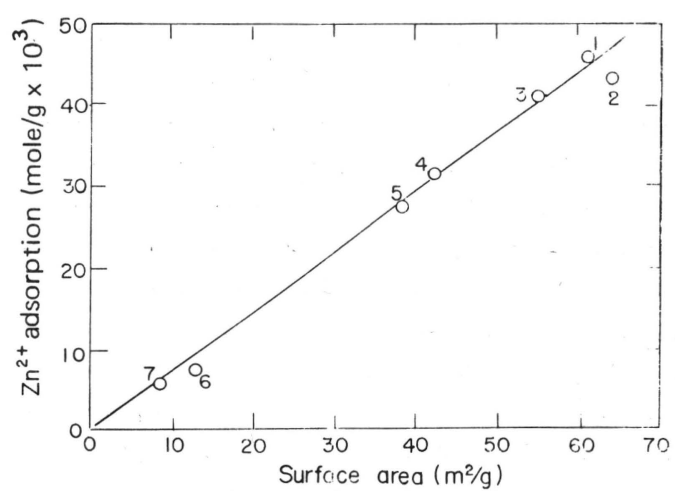

$2 \mathrm{M} / \mathrm{I} . \mathrm{NH}_{4} \mathrm{Cl}, 0.1 \mathrm{M} / \mathrm{I}$. ZnO solution

1. Electrolytic $\mathrm{MnO}_{2}$

2. No. 1 heating at $165^{\circ} \mathrm{C}$

3. No. 1 heating at $320^{\circ} \mathrm{C}$

4. No. 1 heating at $450^{\circ} \mathrm{C}$

5. Natural ore

6. Natural pyrolusite

7. $\mathrm{Mn}_{2} \mathrm{O}_{3}$ prepared from electrolytic $\mathrm{MnO}_{2}$ by heating at $650^{\circ} \mathrm{C}$ for $6 \mathrm{hr}$.

Fig. 9 Relation between the surface area measured by BET and the $\mathrm{Zn}$ adsorption (A. Kozawa)

importance. As early as in 1926, Ghosh 63) discovered that manganese dioxide possesses the ability to exchange and adsorb cations. Sasaki, Kurano and Fushiya ${ }^{64)}$ disclosed that manganese dioxide has a pH-buffer ability which comes from ion-exchange property. Johnson and Vosburgh ${ }^{65)}$ also investigated the ion-exchange capacity with respect to $\mathrm{Na}^{+}$and $\mathrm{NH}_{4}{ }^{+}$ions. The $\mathrm{Zn}^{2+}$ ion adsorption by manganese dioxide was studied by Kozawa ${ }^{66)}$. The proportional relationship shown in Fig. 9 between the ion exchange capacity and the surface area was found to be measured by the BET method.

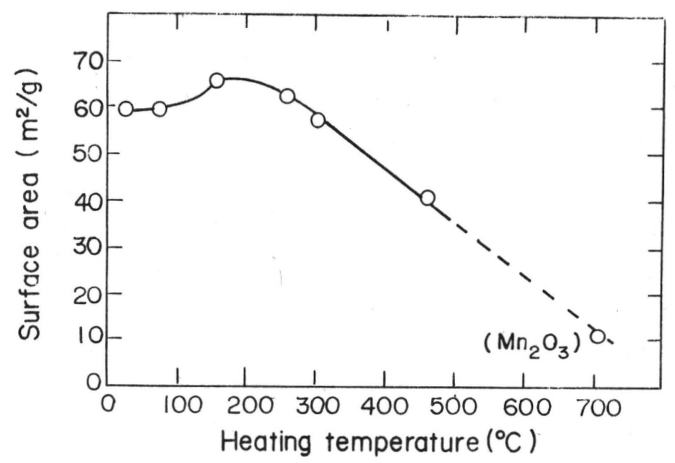

Fig. 10 Surface area change of electroly tic manganese dioxide on heating (A. Kozawa) 
Fig. 10 shows the change of BET surface area by heat application. Appelt ${ }^{67)}$ observed no definite proportional relationship between the cation exchange capacity and BET surface area as observed by Kozawa, in spite of decline of cation exchange capacity due to heat treatment. Muller, Tye and Wood ${ }^{68)}$ reported that there is a proportional relationship between the water vapour absorbing capacity (this has something to do with porosity), and the ion-exchange capacity of manganese dioxide as shown in Fig. 11. And they

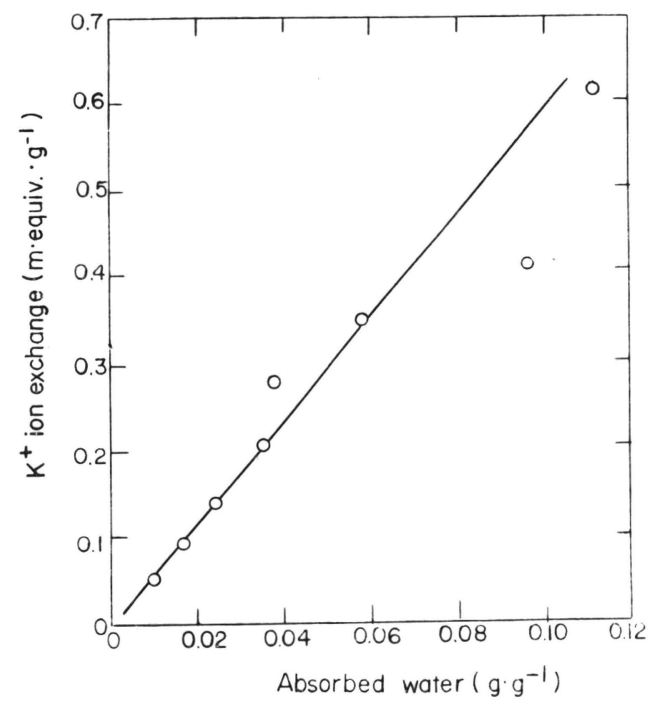

Fig. 11 Plot of potassium exchange against absorbed water (J. Muller, F. L. Tye, and L. L. Wood)

also found that the manganese dioxide possessing larger quantity of combined water had a tendency to adsorb amount of cations from an external solution. In order that manganese dioxide may be able to exchange and adsorb cations, it will be prerequisite that manganese dioxide should set free $\mathrm{H}^{+}$ions. The $\mathrm{H}^{+}$departing from manganese dioxide might be assumed to originate from the $\mathrm{OH}$ group which forms the combined water. However, Kozawa proposed a mechanism shown in Fig. 12 for the ion-exchange reaction on the surface of manganese dioxide. The departing $\mathrm{H}^{+}$ion does not come from the $\mathrm{OH}$ group of the combined water but from the $\mathrm{H}_{2} \mathrm{O}$ molecules adsorbed from the solution onto the surface of manganese dioxide. His explanation satisfies the experimental obser-

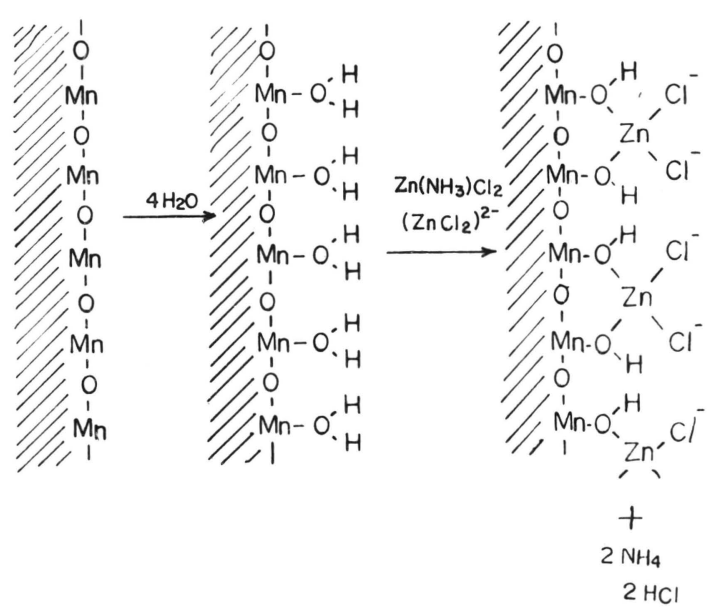

Fig. 12 Mechanism of ion exchange reaction on surface of $\mathrm{MnO}_{2}$ (A. Kazawa)

vation that when manganese dioxide containing as much as 8.7 per cent $\mathrm{H}_{2} \mathrm{O}$ is heated to $300^{\circ} \mathrm{C}$, its $\mathrm{H}_{2} \mathrm{O}$ content is reduced to 0.8 per cent or less, but it still retains a considerable ion exchange capacity. This view of Kozawa receives support from Gavano, Etienne and Laurent ${ }^{69}$ )

Kozawa ${ }^{70)}$ concluded that the cationexchange capacity or the surface area is a major factory for determining the activity of manganese dioxide. Although Brenet said that the difference of activity between gamma- $\mathrm{MnO}_{2}$ and beta $-\mathrm{MnO}_{2}$ is due to the presence or absence of $\mathrm{OH}$ group, Kozawa's explanation is that this difference is to be ascribed to the magnitude of surface area. His experiment ${ }^{71}$ ) showed that the electrolytic manganese dioxide having a larger surface area, which is prepared under such conditions as higher current density and lower bath temperature, exhibites smaller discharge overpotential when it is discharged in the acid electrolyte solution. Fukuda, Hirai and Manabe 72),73) measured the surface area of 22 kinds of natural and artificial manganese dioxides by the BET method, and found no definite tendency that a sample of larger surface area has a higher depolarizing activity. For example, a sample having of $28 \mathrm{~m}^{2} / \mathrm{g}$ of surface area shows a higher activity than others having 50 to $55 \mathrm{~m}^{2} / \mathrm{g}$ of surface area. Era, Takehara and Yoshizawa ${ }^{74}$ ) measured the suraface area, discharge overpotential and discharge capacity of 12 kinds of electro- 
lytic manganese dioxides prepared under various conditions, and investigated the discharge overpotential and discharge capacity in terms of surface area, finding that so far as electrolytic manganese dioxide is concerned the activity becomes higher with the decrease of surface area.

It may be impossible to discuss the activity of manganese dioxide without regarding its surface characteristics. At the present stage of investigation, however, no definite conclusion has been formed about the relationship between the activity and surface characteristics, e.g., BET surface area.

It is well known that innumerable fine pores are distributed on the surface of manganese dioxide, particularly of electrolytic one. There are many attempts to measure these pores 66$), 75), 76)$, but no efforts seem to have been made to elucidate the bearing of the mean diameter and distribution of these pores on the activity. It is of importance to study these factors in connection with the activity of manganese dioxide.

Another important factor determining the activity of manganese dioxide is the crystal structure. Manganese dioxide has many crystal phases including $a$-(mineral cryptomelane), $\beta$ - (mineral pyrolusite), $\gamma$-, and $\delta-\mathrm{MnO}_{2}$. Other phases such as $\left.\epsilon-,{ }^{77} \sim 80\right)$ and $\rho-\mathrm{MnO}_{2}{ }^{81)}$ were also reported. Among these, $\gamma-\mathrm{MnO}_{2}$ is proven to be the most active. ${ }^{82}$ ) The $\gamma-\mathrm{MnO}_{2}$ occurs in nature and is artificially produced as well. The activity of $\gamma-\mathrm{MnO}_{2}$, however, widely varies. Fukuda ${ }^{83)} \sim 85$ ) investigated the detail of crystal structure of $\gamma-\mathrm{MnO}_{2}$ by $\mathrm{X}$-ray diffractometry and classified it into synthetic hydrous ramsdellite- (s.h.r.), artificial ramsdellite-like-, natural ramsdellite-like-, and ramsdellite-phases. The hydrous degree of the phases decreases in the order described above. The activity is the highest of s.h.r. From the fact that the well crystallized mineral ramsdellite is much inferior in activity to the s.h.r., there occurred a misleading conception that the active $\gamma-\mathrm{MnO}_{2}$ gives broad X-ray diffraction pattern. Fukuda ${ }^{83}$ ) and others ${ }^{74}$ ) observed that the manganese dioxide is more active, which shows rather sharp X-ray diffraction pattern, especially of the line of $d=4 \AA$.

\section{Summary}

Manganese dioxide should be described as having high "activity" to mean that a battery incorporated with it exhibits excellent "discharge capacity". It follows that the most direct method for the determination of "activity" will be one that measures the "discharge capacity" of a given battery in practical conditions. Practically, however, the test method with dry batteries encounters various problems, including:

i) considerable amount of time

ii) various factors relating to the manufacture of batteries, and

iii) ambiguousness of the concept of "discharge capacity"

Consequently, various evaluating method which are more simple to operate have been devised instead of resorting to dry battery tests. Many attempts have been made in an effort to investigate the physical and chemical properties of manganese dioxide which determine the "activity" and consequently elucidate the mechanism of the influence of such properties on "activity". The discharge test by using a simple wet cell is more direct and is more adequate than other physical and chemical methods of determination. Many proposals have been made on the discharge test by wet cell $\left.\left.\left.\left.\left.\left.\left.{ }^{1}\right), 19\right), 20\right), 55\right), 86\right), 87\right), 88\right)$. In this case, however, the method encounters many problems such as of preparation of electrodes, composition of electrolytes, construction of cell, mode of discharge and selection of characteristic values. As a matter of course, no universal evaluating values can be obtained unless these factors are standerized on certain level.

It is by all means improper that there exists no criterion for the determination and evaluation of "activity", which is the most important property of manganese dioxide. Great hopes are entertained of the establishment of a more reasonable evaluating method. 


\section{Literature:}

1) for example, JIS (Japanese Industrial Standard) K-1467 (1965).

2) for example, Signal Corps, Technical Requirement SCL-3175 (1955).

3) for example. H.F. McMurdie, E. Golovato, J. Res. Natl. Bur. Std. 41, 589 (1948).

4) M. Fukuda, Denki-Kagaku 28, 67 (1960).

5) C. Drotschmann. "Modern Primarbatterien" S133 (1951). Nikolaus Branz, Berlin-Schönberg.

6) M. Fukuda, National Technical Report 3, 1(1957).

7) K. Sasaki, "Denchi-Handbook" (Japanese) Tokyo P. 271 (1965).

8) M. Fukuda, National Technical Report 7, 11 (1961).

9) J. P. Brenet, Proc. CITCE 7th Meeting (1955), Lindaw.

10) N. C. Cahoon G. W. Heise, Trans. Electrochem. Soc. 94, 214(1948).

11) M. Fukuda, National Technical Report 3, 207 (1957).

12) M. Fukuda, T. Hirai, H. Manabe, Denki-Kagaku, 27, 247 (1959).

13) T. Hirai. M. Fukuda, ibid. 29, 471 (1961).

14) T. Hıra1, M. Fukuda, ibid. 29, 546 (1961).

15) T. Hirai, M. Fukuda, ibid. 29, 794 (1961).

16) C. Drotschmann, Z. Elektrochem. 54, 304 (1950).

17) N. C. Cahoon, Trans. Electrochem. Soc. 92, 159 (1947).

18) M. Iwasaki, A. Mori, T. Nishi, S. Okada, Denki -Kagaku 22, 578 (1954).

19) K. Sasaki, A. Kozawa, ibid. 25, 273 (1957).

20) N. C. Cahoon, J. Electrochem. Soc. 99, 343 (1952).

21) D. T. Ferrell Jr., W. C. Vosburgh, ibid. 98, 334 (1951).

22) A. Era, Z. Takehara, S. Yoshizawa, Denki-Kagaku 34, 655 (1966).

23) E. Divers, Chem. News 46, 259 (1882).

24) A. Keller, Z. Elektrochem. 37, 342 (1931).

25) N. C Cahoon, R. S. Johnson, M. P. Korver, J. Electrochem. Soc. 105, 296 (1958).

26) A. M. Chreitzberg Jr., D. R. Allenson, W. C. Vosbuigh, ibid. 102, 557 (1957).

27) K. Neumann, W. Fink, Z. Elektrochem. 62, 114 (1958).

28) L. C. Copeland, F. S. Griffith, Trans Electrochem. Soc. 89, 495 (1946).

29) J. Brenet, Proc. CITCE 8th Meeting, (1956), Madrid.

30) H. Bode, A. Schmier, D. Brendt, Z. Elektrochem. 66, 586 (1962).

31) K. J. Vetter, ibid. 66, 577 (1962).

32) R. S. Johnson, W. C. Vosburgh, J. Electrochem. Soc. 100, 471 (1953).

33) A. Era, Z. Takehara, S. Yoshizawa, Denki-Kagaku 34, 483 (1966).
34) A. Kozawa, R. A. Powers, J. Electrochem. Soc. 113, 870 (1966).

35) S. Matsuno, Denki-Kagaku 12, 2 (1944).

36) H. F. McMurdie, Trans. Electrochem. Soc. 86, 313 (1944).

37) H. F. McMurdie, D. N. Craig, G. W. Vinal ibid. 90, 509 (1946).

38) F. Griffith, ibid. 92, 172 (1947).

39) M. P. Korver, R. S. Johnson, N. C. Cahoon, J. Electrochem. Soc. 107, 587 (2960).

40) A. D. Wadselev. A. Walkley, ibid. 95, 11 (1949).

41) N. C. Cahoon, ibid. 99, 344 (1952).

42) I. Muraki, K. Shinoda, Kogyo Kagaku Zasshi 64, 2094 (1961)

43) A. Kozawa, K. Sasaki, Denki-Kagaku 22, 569 (1954).

44) A. Kozawa, K. Sasaki, ibid. 22, 571 (1954).

45) A. Kozawa, K. Sasaki, ibid. 25, 322 (1957).

46) J. J. Coleman, Trans. Electrochem. Soc. 90, 545 (1946).

47) A. B. Scott, J. Electrochem. Soc. 107, 941 (1960)

48) F. Kornfeil, ibid. 109, 349 (1962).

49) A. Kozawa, J. F. Yeager, ibid. 112, 959 (1965).

50) A. Era, Z. Takehara, S. Yoshizawa, Denki-Kagaku 34, 649 (1966).

51) A. Kozawa, K. Sasaki, ibid. 22, 501 (1954).

52) S. Yoshizawa, W. C. Vosburgh, J. Electrochem. Soc. 104, 399 (1957).

53) S. Yoshizawa, Z. Takehara, Denki-Kagaku 34, 588 (1966).

54) A. Era, Z. Takehara, S. Yoshizawa, ibid. 34, 696 (1966).

55) K. Appelt, H. Purol, Electrochimica Acta 1, 326 (1959).

56) PH, Brouillet, A. Grund, F. Jolas, R. Mullet, 4th Intern. Symposium on Batteries, (1964), Brighton.

57) J. Brenet, A. Grund, Compt rend. 240, 1210 (1955).

58) K. Sasaki, A. Kozawa, Denki-Kagaku 25, 115 (1957).

59) E. O. Jegge, Trans. Electrochem. Soc. 53, 71 (1928).

60) O. Glemser, H. Meisiek, Naturwissenschaften 44, 614 (1957).

61) O. Glemser, G. Gattow, H. Meisiek, Z. anorg. allgem. Chem. 309, 121 (1961).

62) J. Brenet, "Batteries" P. 357 (1963), Pergamon Press.

63) B. Ghosh, J. Chem. Soc. 2605 (1926).

64) K. Sasaki, T. Kurano, Y. Fushiya, Denki-Kagaku 4, 67 (1936).

65) R. S. Johnson, W. C. Vosburgh, J. Electrochem. Soc. 99, 317 (1952).

66) A. Kozawa, ibid. 106, 552 (1959).

67) K. Appelt et al, Electrochimica Acta 8, 559 (1963)

68) J. Muller, F. L. Tye, L. L. Wood. " 4 th Intern. Symposium on Batteries", (1964), Brighton.

69) J. P. Gavano, T. E. Tienne, J. F. Laurent, Electrochimica Acta 10, 947 (1965). 
70) A. Kozawa, R. A. Powers, "Electrochem. Soc. Fall Meeting" (1966).

71) A. Kozawa, W. C. Vosburgh, J. Electrochem. Soc. 105, 59 (1958).

72) M. Fukuda, T. Hirai, H. Manabe, National Tech. Report 5, 127 (1959).

73) M. Fukuda, T. Hirai, H. Manabe, Denki-Kagaku 27, 204 (1959).

74) A. Era, Z. Takehara, S. Yoshizawa, ibid. 35, 334 (1967)

75) N. C. Cahoon, M. P. Korver, J. Electrochem. Soc. 109, 1 (1962).

76) S. Ninagi, Y. Miyake, Denki-Kagaku 30, 727 (1962).

77) S. Okada, I. Uei, H. Chin, Denki-Kagaku 15, 79 (1947).

78) O. Glemser, H. Meisiek, Angew. Chem 69, 534 (1957).
79) O. Glemser, H. Meisiek, J. prakt. Chem. 4, 219 (1958).

80) J. Brenet, L. Pons, Compt. Rend. 260, 2483 (1965).

81) H. Kedesdy, G. Gatz, S. L. Levin, Acta Cryst. 12, 780 (1957).

82) H. F. McMurdie, E. Golovato, J. Res. Natl. Bur. Std. 38, 415 (1947).

83) M. Fukuda, National Technical Report 4, 321 (1958).

84) M. Fukuda, ibid. 5, 1 (1959).

85) M. Fukuda, Denki-Kagaku 28, 67 (1960).

86) C. K. Morehause, R. Glicksman, J. Electrochem. Soc. 103, 94 (1056).

87) F. Kornfeil, ibid. 106, 1062 (1959).

88) R. H. W. Sien, "Symposium on $\mathrm{MnO}_{2}$ in Dry Cell" (1964), Amsterdam. 